\title{
A STATISTICAL APPROACH TO EVALUATING EFFICIENCY OF BANKS
}

Milica Bulajica, Veljko Jeremic $c^{b}$, Snezana Knezevic ${ }^{c}$, Nevenka Zarkic-Joksimovic ${ }^{d}$

${ }^{a}$ Full Professor, PhD, University of Belgrade, Faculty of Organizational Sciences, Jove llica 154, 11000 Belgrade, Serbia, bulajic.milica@fon.bg.ac.rs.

${ }^{b}$ Assistant Professor, PhD, University of Belgrade, Faculty of Organizational Sciences, Jove llica 154, 11000 Belgrade, Serbia, jeremic.veljko@fon.bg.ac.rs.

'Associate Professor, PhD, University of Belgrade, Faculty of Organizational Sciences, Jove Ilica 154, 11000 Belgrade, Serbia, knezevic.snezana@fon.bg.ac.rs.

${ }^{d}$ Full Professor, PhD, University of Belgrade, Faculty of Organizational Sciences, Jove llica 154, 11000 Belgrade, Serbia, zarkicjoksimovic.nevenka@fon.bg.ac.rs.

\section{ARTICLE INFO}

Article data:

- Received: 10 December 2012

- Accepted: 11 October 2013

JEL classification: C38, C44, G21

Keywords:

- efficiency of banks

- I-distance method

- multivariate statistical methods

\section{ABSTRACT}

Evaluating efficiency of banks has always represented a challenge for researchers. Although many different methods have been proposed, no particular approach is agreed upon. In this paper, statistical I-distance method is proposed. We employed this method on the Serbian banks in the five-year period. Results obtained by I-distance methodology are presented and thoroughly elaborated.

Reference to this paper should be made as follows: Bulajic, M., Jeremic, V., Knezevic, S., Zarkic-Joksimovic, N. 2013. A statistical approach to evaluating efficiency of banks, Ekonomskaistraživanja - Economic Research 26(4): 91-100 


\section{INTRODUCTION}

Serbian industry went through a long period of recession in the 90s. Banking industry was faced with decreasing of performances, undeveloped financial market, absence of an appropriate legal framework, etc. In the last decade, comprehensive changes in industrial sector, legal system and institutions, and, consequently, in the banking system, have occurred. The process of economy revitalization and restructuring of the banking system began in 2001 (Knezevic et al., 2011a). Out of about fifty banks owned by the state, which operated under very bad and nontransparent conditions and without trust from clients and Serbia's population at that time, now, on the same market, there are over twenty foreign-owned banks and only few domestic, private or state-owned (Djuric, 2010; Knezevic et al., 2010; Bulajic et al., 2011). All of them operate under significantly different conditions, under strong control by the National Bank of Serbia (NBS), which adopted many regulations that are being applied in the European Union as well.

Decrease of the number of banks is an expected trend in the following period, through further consolidation of the banking sector, under the influence of the country's strategy on the question of its share in the ownership of banks. It is expected that further growth of banks will influence the increase of competition. In a line with this, it is vital to evaluate efficiency of banks (Khailuk\&Melnyk, 2010; Sufian, 2010; Sufian\&Habibullah, 2010; Barros et al., 2011; Efendic\&Avdic, 2011; Knezevic et al., 2011b; Taboada, 2011). In this paper, novel statistical I-distance approach will be employed.

\section{THE I-DISTANCE METHOD}

Quite often, the ranking of specific marks is done in a way that can seriously affect the process of taking exams, sport competitions, UN participation, Universities ranking, medicine selection and many others (Al-Lagilli et al., 2011; Ivanovic, 1973; Ivanovic and Fanchette, 1973; Jeremic and Radojicic, 2010; Jeremic et al., 2011a).

$\mathrm{I}$-distance is a metric distance in an $\mathrm{n}$-dimensional space. It was proposed and defined by $\mathrm{B}$. Ivanovic in various publications that have appeared since 1963 (Ivanovic, 1973). Ivanovic devised this method to rank countries according to their level of development based on several indicators. Many socio-economic development indicators were considered and the problem was how to use all of them in order to calculate a single synthetic indicator, which will thereafter represent the rank.

For a selected set of variables $X^{T}=\left(X_{1}, X_{2}, \ldots, X_{k}\right)$ chosen to characterize the entities, the I-distance between the two entities $e_{r}=\left(x_{1 r}, x_{2 r}, \ldots, x_{k r}\right)$ and $e_{s}=\left(x_{1 s}, x_{2 s}, \ldots, x_{k s}\right)$ is defined as

$$
D(r, s)=\sum_{i=1}^{k} \frac{\left|d_{i}(r, s)\right|}{\sigma_{i}} \prod_{j=1}^{i-1}\left(1-r_{j i .12 \ldots j-1}\right)
$$

where $d_{j}(r, s)$ is the distance between the values of variable $X_{i}$ for $e_{r}$ and $e_{s}$, e.g. the discriminate effect,

$$
d_{i}(r, s)=x_{i r}-x_{i s}, i \in\{1, \ldots, k\}
$$


$\sigma_{i}$ the standard deviation of $X_{i}$, and $r_{j i .12 \ldots j-1}$ is a partial coefficient of the correlation between $X_{i}$ and $X_{j},(j<i)$, (Ivanovic, 1973; Jeremic et al., 2011d).

The construction of the I-distance is iterative; it is calculated through the following steps:

- Calculate the value of the discriminate effect of the variable $\mathrm{X}_{1}$ (the most significant variable, that which provides the largest amount of information on the phenomena that are to be ranked (Ivanovic, 1977))

- Add the value of the discriminate effect of $X_{2}$ which is not covered by $X_{1}$

- Add the value of the discriminate effect of $X_{3}$ which is not covered by $X_{1}$ and $X_{2}$

- $\quad$ Repeat the procedure for all variables (Mihailovic et al., 2009; Jeremic et al., 2011e).

Sometimes, it is not possible to achieve the same sign mark for all variables in all sets, and, as a result, a negative correlation coefficient and a negative coefficient of partial correlation may occur (Jeremic et al., 2011b; Jeremic et al., 2012). This makes the use of the square I-distance even more desirable. The square I-distance is given as:

$$
D^{2}(r, s)=\sum_{i=1}^{k} \frac{d_{i}^{2}(r, s)}{\sigma_{i}^{2}} \prod_{j=1}^{i-1}\left(1-r_{j i .12 \ldots j-1}^{2}\right)
$$

In order to rank the entities (in this case, banks), it is necessary to have one entity fixed as a referent in the observing set using the I-distance methodology. The entity with the minimal value for each indicator or a fictive maximal or average values entity can be set up as the referent entity. The ranking of entities in the set is based on the calculated distance from the referent entity (Jeremic et al., 2011c; Radojicic et al., 2012).

The basic idea of this paper is to apply the I-distance method into several input indicators

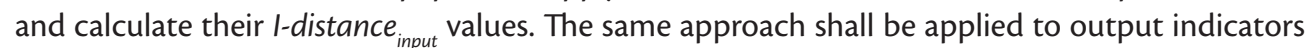
and I-distance ${ }_{\text {output }}$ values will be calculated as well. Obtained values will be brought to 0-1 level by implementing L $\infty \infty$ norm. The efficiency of bank will be calculated as EF $=1$-distance ${ }_{\text {output }} /$ I-distan$c e_{\text {input }}$. Any bank with an efficiency ratio of at least 1 is to be considered as efficient.

\section{RESULTS}

I-distance method was performed on 27 banks that worked on Serbian market in the period of 2006-2010. At the end of 2010, 34 banks existed in Serbia but only those with full data for the period 2006-2010 were incorporated into analysis. This seven missing banks participated in only $1 \%$ of Serbian banking market and thus were irrelevant for the analysis. After performing factor analysis on the fourteen existed variables, seven variables were incorporated into analysis: as the input variables (I1) sources, (12) liquid assets, (13) cash, (14) portfolio and (15) number of employees; on the other hand, as the output variables (O1) CBNI (core net business income) and (O2) NII (net interest income) were used.

The results achieved through the use of the I-distance method are presented in Table 1. 
Milica Bulajic, Veljko Jeremic, Snezana Knezevic, Nevenka Zarkic - Joksimovic

TABLE 1. I-DISTANCE EFICIENCY SCORES AND CLUSTERS

\begin{tabular}{|c|c|c|c|c|c|c|c|c|c|c|c|}
\hline & & Bank & 2006 & 2007 & 2008 & 2009 & 2010 & $\operatorname{Min}$ & $\operatorname{Max}$ & Avg & Rank \\
\hline \multirow{5}{*}{ 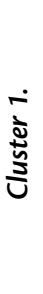 } & \multirow{5}{*}{ 节 } & AIK banka & 1,487 & 0,531 & 1,274 & 1,484 & 1,597 & 0,531 & 1,597 & 1,275 & 1 \\
\hline & & Societe Generale & 1,288 & 1,387 & 1,199 & 1,079 & 1,044 & 1,044 & 1,387 & 1,199 & 2 \\
\hline & & EFG Eurobank & 1,097 & 1,357 & 1,177 & 1,092 & 1,068 & 1,068 & 1,357 & 1,158 & 3 \\
\hline & & Agrobanka & 0,917 & 0,713 & 1,253 & 1,157 & 1,501 & 0,713 & 1,501 & 1,108 & 4 \\
\hline & & Banca Intesa & 1,221 & 1,000 & 1,000 & 1,000 & 1,101 & 1,000 & 1,221 & 1,064 & 5 \\
\hline \multirow{7}{*}{ 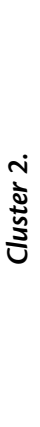 } & \multirow{7}{*}{ 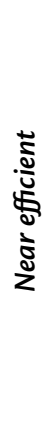 } & UniCredit bank & 0,868 & 0,894 & 0,615 & 0,950 & 1,151 & 0,615 & 1,151 & 0,895 & 6 \\
\hline & & OTP banka & 1,144 & 1,255 & 0,993 & 0,859 & 0,150 & 0,150 & 1,255 & 0,880 & 7 \\
\hline & & Univerzal banka & 0,596 & 0,979 & 0,948 & 0,654 & 0,805 & 0,596 & 0,979 & 0,796 & 8 \\
\hline & & RB Vojvodine & 0,645 & 0,818 & 0,572 & 0,796 & 1,062 & 0,572 & 1,062 & 0,778 & 9 \\
\hline & & Erste bank & 0,274 & 0,511 & 0,844 & 1,101 & 0,995 & 0,274 & 1,101 & 0,745 & 10 \\
\hline & & Raiffeisenbank & 0,898 & 0,908 & 1,082 & 0,551 & 0,265 & 0,265 & 1,082 & 0,741 & 11 \\
\hline & & ProCredit bank & 1,187 & 0,713 & 0,492 & 0,590 & 0,691 & 0,492 & 1,187 & 0,734 & 12 \\
\hline \multirow{10}{*}{ 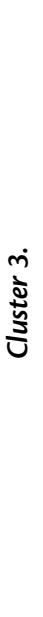 } & \multirow{10}{*}{ 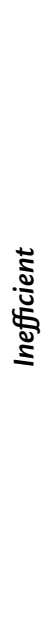 } & Credit Agricole bank & 1,002 & 0,389 & 0,389 & 0,968 & 0,474 & 0,389 & 1,002 & 0,644 & 13 \\
\hline & & Piraeus bank & 0,106 & 0,428 & 0,809 & 0,618 & 0,918 & 0,106 & 0,918 & 0,575 & 14 \\
\hline & & Čačanska banka & 0,378 & 0,263 & 0,709 & 0,380 & 0,960 & 0,263 & 0,960 & 0,538 & 15 \\
\hline & & Hypo-Alpe-Adria bank & 0,410 & 0,181 & 0,558 & 0,880 & 0,652 & 0,181 & 0,880 & 0,536 & 16 \\
\hline & & Srpska banka & 1,049 & 0,263 & 0,118 & 0,412 & 0,825 & 0,118 & 1,049 & 0,533 & 17 \\
\hline & & Poštanska štedionica & 0,994 & 0,033 & 0,525 & 0,555 & 0,548 & 0,033 & 0,994 & 0,531 & 18 \\
\hline & & NLB banka & 0,485 & 0,282 & 0,841 & 0,540 & 0,334 & 0,282 & 0,841 & 0,496 & 19 \\
\hline & & Komercijalna banka & 1,041 & 0,597 & 0,368 & 0,256 & 0,205 & 0,205 & 1,041 & 0,494 & 20 \\
\hline & & Volks banka & 0,130 & 0,246 & 0,268 & 0,706 & 1,060 & 0,130 & 1,060 & 0,482 & 21 \\
\hline & & Alpha bank & 0,853 & 0,550 & 0,431 & 0,050 & 0,236 & 0,050 & 0,853 & 0,424 & 22 \\
\hline \multirow{5}{*}{ 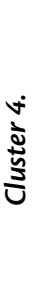 } & \multirow{5}{*}{ 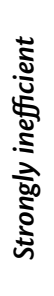 } & KBC banka & 0,205 & 0,569 & 0,108 & 0,654 & 0,179 & 0,108 & 0,654 & 0,343 & 23 \\
\hline & & Vojvođanska banka & 0,079 & 0,477 & 0,576 & 0,227 & 0,129 & 0,079 & 0,576 & 0,298 & 24 \\
\hline & & Marfin bank & 0,154 & 0,276 & 0,076 & 0,495 & 0,423 & 0,076 & 0,495 & 0,285 & 25 \\
\hline & & PB Beograd & 0,029 & 0,114 & 0,027 & 0,170 & 0,259 & 0,027 & 0,259 & 0,120 & 26 \\
\hline & & Credy banka & 0,043 & 0,028 & 0,025 & 0,330 & 0,014 & 0,014 & 0,330 & 0,088 & 27 \\
\hline
\end{tabular}

Source: author calculation 
As we can see, efficiency of banks has changed dramatically over period. Only three banks (SocieteGenerale, EFG Eurobank and Bancalntesa) were efficient in all five years. Overall, the worst average efficiency was determined in the years 2007 and 2008. The values of efficiency scores for each bank obtained for the five-year period and presented in Table 1, can be used in order to detect the similarities and differences among the banks in Serbia and to group them, consequently. Ward method for hierarchical clustering is used and four clusters of the banks are identified. Cluster 1 consists of five banks, classified as Efficient at the top of the ranking list, whose efficiency scores have been in average greater than 1. Sevenbanks, classified after these in the Cluster 1, belong to the Cluster 2 (Near efficient). Their efficiency scores vary around 1, as their performances have changed during observed period. The average scores for the banks in Cluster 2 are from 0.734 to 0.895 . They have not been always efficient, but close to it. Among the first twelve banks, belonging to the Clusters 1 and 2, there is only one bank (AIKbanka) which is not completely foreign ownership.

Cluster 3 (Inefficient) comprises next 10 banks with ranks between 13 and 22 and average efficiency scores from 0.424 and 0.644 . Most of them have been inefficient in each of the five analyzed years. Entities that belong to this inefficient group are foreign, medium banks, in term of total assets value. These banks are more efficient than last 5 banks, belonging to the Cluster 4 (Strongly inefficient). The most efficient bank in the Cluster 4 has average efficiency score 0.343 . Others are even more inefficient, dominantly small domestic, state owned banks which are planned for ownership transitions in near future.

The main descriptive parameters for average efficiency scores and corresponding boxplot for the clustered banks are given in Table 2 and Figure 1.

TABLE 2. DESCRIPTIVE STATISTICS FOR AVERAGE EFFICIENCY SCORES INCLUSTERS

\begin{tabular}{ccccc}
\hline $\begin{array}{c}\text { Average } \\
\text { efficiency score }\end{array}$ & $\begin{array}{c}\text { Cluster 1 } \\
\text { Efficient }\end{array}$ & $\begin{array}{c}\text { Cluster 2 } \\
\text { Near efficient }\end{array}$ & $\begin{array}{c}\text { Cluster 3 } \\
\text { Inefficient }\end{array}$ & $\begin{array}{c}\text { Cluster 4 } \\
\text { Strongly inefficient }\end{array}$ \\
\hline \hline Mean & 1.160 & 0.795 & 0.525 & 0.226 \\
Std. Deviation & 0.081 & 0.066 & 0.058 & 0.114 \\
Minimum & 1.064 & 0.734 & 0.424 & 0.088 \\
Maximum & 1.275 & 0.895 & 0.644 & 0.343 \\
\# of banks & 5 & 7 & 10 & 5 \\
\hline \hline
\end{tabular}

Source: author calculation 


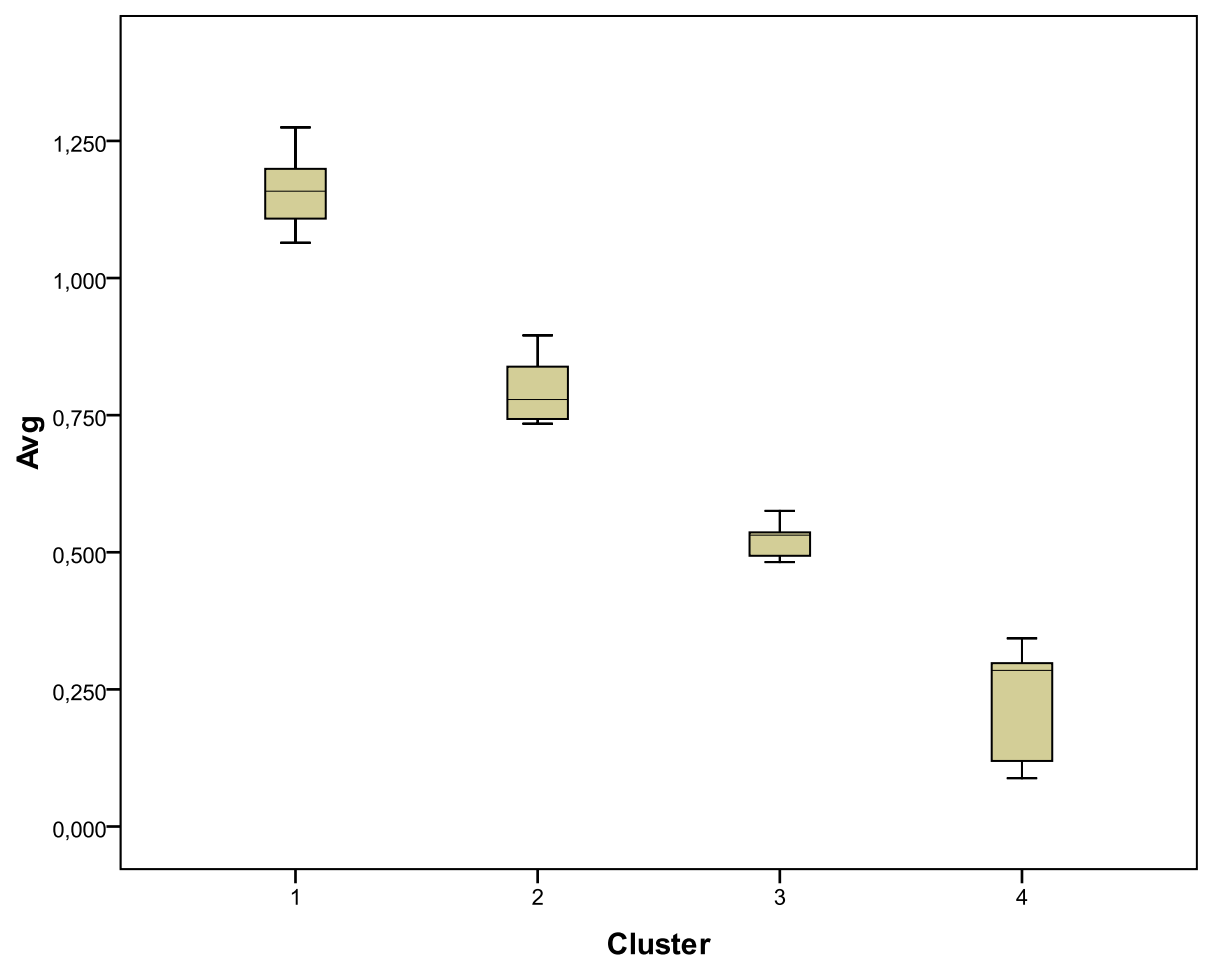

FIGURE 1. BOXPLOT FOR AVERAGE EFFICIENCY SCORES

Source: author calculation

\section{CONCLUSION}

The main advantage of the I-distance method is the possibility of taking multiple heterogeneous indicators into consideration when the efficiency of organizational units is to be evaluated (Knezevic et al. 2012). Index obtained as the indicator of the efficiency by I-distance is relative and depends on number of parameters and organizational units in observing set. At the same time it determines the rank of the unit. Using I-distance in the analysis of banks' efficiency allows us to identify the market leaders, who follows them, but who is very inefficient, too (Bulajicet al., 2011). The statistical model developed and applied as presented in this paper enables clear description of the situation in banking sector of the country for the period if interest. According to the I-distance results, there is an obvious general trend of average performance decrease of banks during crisis years. Partly, the crisis itself can be blamed for that, and partly increase of competition among banks. Another trend is efficiency increase of banks that went through privatization process, i.e. ownership change. The thing that marks the whole period is extreme inefficiency of smaller state owned banks, while domestic larger banks are very efficient and are successfully struggling with foreign competition. 


\section{ACKNOWLEDGEMENTS}

We would like to thank anonymous referees and Sanja Blažević (executive editor) for outstanding handling the paper and all the energy she introduced into this process. 


\section{REFERENCES}

Al-Lagilli, S., Jeremic, V., Seke, K., Jeremic, D. and Z.Radojicic."Evaluating the health of nations: a Libyan perspective", Libyan Journal of Medicine, 6, 6021,(2011), doi: 10.3402/ljm.v6i0.6021

Barros, C.P., Chen, Z.P., Liang, Q.B. and N. Peypoch."Technical efficiency in the Chinese banking sector", Economic Modeling, 28 (5), (2011): 2083-2089.doi: 10.1016/j.econmod.2011.04.003.

Bulajic, M., Savic, G., Savic, S., Mihailovic, N. and M. Martic."Efficiency assessment of banks in Serbia", TTEM - Technics Technologies Education Management, 6(3), (2011): 657-662.

Djuric, D."Management accounting statements for the purpose of decision making in banks", Management, 15(55), (2010): 17-24.

Efendic, V. and A.Avdic."An analysis on the efficiency of banks in Bosnia and Herzegovina using DEA method", TTEM - Technics Technologies Education Management, 6(1), (2011): 147-158.

Ivanovic, B.A method of establishing a list of development indicators, UNESCO, Paris, 1973.

Ivanovic, B.Classification Theory, Institute for Industrial Economic, Belgrade, 1977.

Ivanovic, B. and S. Fanchette. Grouping and ranking of 30 countries of Sub-Saharan Africa, Two distance-based methods compared, UNESCO, Paris, 1973.

Jeremic, V. and Z.Radojicic."A New Approach in the Evaluation of Team Chess Championships Rankings", Journal of Quantitative Analysis in Sports, 6(3), (2010): Article 7. doi: 10.2202/1559-0410.1257

Jeremic, V., Bulajic, M., Martic, M. and Z.Radojicic."A fresh approach to evaluating the academic ranking of world universities", Scientometrics, 87(3), 2011a: 587-596. doi: 10.1007/ s11192-011-0361-6

Jeremic, V., Isljamovic, S., Petrovic, N., Radojicic, Z., Markovic, A. and M. Bulajic."Human development index and sustainability: What's the correlation?",Metalurgia International, 16(7), 2011b: 63-67.

Jeremic, V., Vukmirovic, D., Radojicic, Z. and A. Djokovic."Towards a framework for evaluating ICT infrastructure of countries: a Serbian perspective", Metalurgia International, 16(9), 2011c: $15-18$.

Jeremic, V., Markovic, A. and Z. Radojicic."ICT as crucial component of socio-economic development", Management, 16(60), 2011d: 5-9.

Jeremic, V., Seke, K., Radojicic, Z., Jeremic, D., Markovic, A., Slovic, D. and A. Aleksic."Measuring health of countries: a novel approach", HealthMED, 5(6), 2011e: 1762-1766.

Jeremic, V., Slovic, D. and Z. Radojicic."Measuring human capital: a statistical approach", Actual Problems of Economics, 131, (2012): 359-363.

Khailuk, S.O. and T. M. Melnyk."Application of nonparametric methods of estimating efficiency, effectiveness and performance of domestic banks", Actual Problems of Economics, 113, (2010): 263-276.

Knezevic, S., Jeremic, V., Zarkic-Joksimovic, N. and M. Bulajic. "Evaluating the Serbian banking sector: a statistical approach", Metalurgia International, 17(1), (2012): 171-174. 
Knezevic, S., Milosavljevic, M. and V. Dmitrovic."Importance of strategic management accounting for bank management", Management, 15(57), (2010): 23-29.

Knezevic, S., Dmitrovic, V., Jovanovic, M. and T. Obradovic."Management of receivables in function of support to business success", Management, 16(58), 2011a: 49-57.

Knezevic, S., Barjaktarovic-Rakocevic, S. and D. Djuric."Management accounting in achieving competitive advantage and bank controlling", Management, 16(59), 2011b: 5-14.

Mihailovic, N., Bulajic, M. and G. Savic."Ranking of banks in Serbia”, YUJOR, 19(2), (2009): $323-$ 334.doi: 10.2298/YUJOR0902323M

Radojicic, Z., Isljamovic, S., Petrovic, N. and V. Jeremic. "A novel approach to evaluating sustainable development", ProblemyEkorozwoju - Problems of Sustainable Development, 7(1), (2012): 81-85.

Sufian, F. "Assessing the impact of financial sector restructuring on bank performance in small developing economy", Ekonomskaistrazivanja - Economic Research, 23(2), (2010): 11-33.

Sufian, F. and M. S. Habibullah.“"Does foreign banks entry fosters bank efficiency? Empirical evidence from Malaysia", InzinerineEkonomika - Engineering Economics, 21(5), (2010): 464-474.

Sufian, F. and M. S. Habibullah."Has economic freedom foster bank performance? Panel evidence from China", Actual Problems of Economics, 121, (2011): 377-388.

Taboada, A.G. "The impact of changes in bank ownership structure on the allocation of capital: International evidence", Journal of Banking \& Finance, 35(10), (2011): 2528-2543. doi: 10.1016/j.jbankfin.2011.02.017 


\title{
STATISTIČKI PRISTUP MERENJU EFIKASNOSTI BANAKA
}

\begin{abstract}
SAŽETAK
Evaluacija efikasnosti banaka je oduvek predstavljala izazov za istraživače.lako su predložene brojne metode, ne postoji opšteprihvaćeni pristup rešavanju dotičnog problema. $U$ našem radu je predložena metoda I - odstojanja koja je primenjena na evaluaciju banaka u Srbiji tokom petogodišnjeg perioda. Dobijeni rezultati su prezentovani i detaljno objašnjeni.
\end{abstract}

Ključne riječi: efikasnost banaka, metoda I - odstojanja, multivarijantna statistička metoda 